\title{
Quantum-chemical calculation of the free energy of binding of vinpocetine molecules with surface of silicon and silicon dioxide
}

\author{
Yulia POLKOVNIKOVA ${ }^{1}{ }^{*}$, Alexandr LENSHIN ${ }^{1}$, Pavel SEREDIN ${ }^{1}$, Kseniya KORYANOVA ${ }^{2}$
}

1 Federal State Budget Educational Institution of Higher Education "Voronezh State University," 394036, Voronezh, ul. Student, 3, Russia.

2 Pyatigorsk Medical and Pharmaceutical Institute - branch of FGBOU in VolgGMU Ministry of Health care of Russia, 357500, Pyatigorsk, Kalinin Ave., 11, Russia.

* Corresponding Author. E-mail: juli-polk@mail.ru (Y.P.); Tel. +79081397582; ORCID No: 0000-0003-0123-9526.

Received: 02 March 2018 / Revised: 27 April 2018 / Accepted: 30 April 2018

\begin{abstract}
An important task in technology of chemical-pharmaceutical preparations is the improvement of drug formulations, the development of new alternative drug delivery methods for biologically active substances as well as the changes in the delivery systems of active components. A search and implementation of nano-size systems for the delivery of drug formulations related to nootropic series is in fact an actual task in medicine. Correct interpretation of the experimental data in the study of the reactant release from the delivery systems such as nanoparticles is impossible without the comprehension of physico-chemical processes occurring at the molecular level. The purpose of the study is a comparative analysis of thermodynamic characteristics of vinpocetine binding with the surface of silicon and silicon oxide in aqueous medium. Calculations of the enthalpy, entropy and Gibbs energy were performed for the process of vinpocetine desorption from the surface of an adsorbent. First, the values of enthalpy and entropy were calculated for the initial and final stages of the process. Gibbs energy of vinpocetine desorption from the surface of silicon oxide is of a greater value as compared with its desorption from silicon surface under corresponding $\mathrm{pH}$ values. It can be explained by the ability of silicon oxide surface to ionization at $\mathrm{pH} 6.8$ and 7.0, as well as by a large number of hydroxyl groups on the surface of this adsorbent. The obtained data enables to make a conclusion on the more tight vinpocetine binding with the surface of silicon oxide as compared with pure silicon surface.
\end{abstract}

KEYWORDS: Vinpocetine; nanoparticles; silicon; silicon dioxide; sorption.

\section{INTRODUCTION}

Targeted drug delivery is one of the most important problems of the up to date pharmacology. First of all it is connected with a low efficiency of the routine ways for the medication intake when only a small part of the drug gets directly to the nidus. Moreover, a lot of the drugs have different side effects limiting permissible doses. Therefore, the development of containers for the targeted drug delivery is one of the main tasks in this scientific area [1-3].

Considerable progress in the field of the development of the principally new drug carriers is connected with the use of nanomaterials. Various substances are currently applied as the drug carriers - polymers, liposomes, hydroxyapatites, particles of metals and their oxides [4-6]. New technologies for obtaining of highporous materials are elaborated that are capable to adsorb drugs and then to release them in a controlled way. This is especially important while formation of the preparations with a prolonged activity [7].

Materials for nano-containers should meet rather severe safety requirements: they must have minimal toxicity and it is desirable that they should be biodegradable [8]. One kind of these materials is nanoparticles of silicon, silicon oxide and porous silicon. The latter material involves both oxidized and non-oxidized silicon phases. The ratio of these phases can be controlled by varying of the technological parameters when obtaining porous silicon and performing its post-treatment $[9,10]$.

Elaboration of the new drug formulations of neuro-psychopharmacology substances is limited by two essential problems: overcoming of hematoencephalic barrier and selectivity of the active agent in respect to the target-cells in central nervous system. In order to solve these problems at the contemporary stage of the

How to cite this article: Polkovnikova Y, Lenshin A, Seredin P, Koryanova K. Quantum-chemical free energy calculation of vinpocetine molecules with surface of silicon and silicon dioxide. Marmara Pharm J. 2018; 22 (4): 474-483. 
development a design of the multi-functional high-selective nanosystems seems to be especially perspective. These nanosystems will be capable to deliver transported agent first to the cerebral micro-vessels, then to the interstitial fluid and thereafter directly to the target-cells in the brain [11]. An important role in solution of these tasks implies the determination of the mechanisms and calculation of the corresponding functional parameters characterizing adsorption and desorption of the medicinal drugs at the particles-carriers of different composition. A prospective pharmaceutical substance for design of the nano-size formulation on the basis of porous silicon is vinpocetine [12].

This article is a continuation in the series of works concerned with the development and investigations of nanostructures on the basis of silicon for the application in the field of targeted delivery of the drugs [13,14].

The purpose of the study is a comparative analysis of thermodynamic characteristics related to the binding of vinpocetine with the surface of silicon and silicon oxide from aqueous medium.

\section{RESULTS}

In order to make quantum-chemical calculations of thermodynamic characteristics the following fragments of the initial and ultimate states used in the simulation of molecular dynamics of the systems were isolated (Figs. 1 - 7): 1) vinpocetine - adsorbent, 2) solvent, 3) adsorbent, 4) vinpocetine - solvent.

Vinpocetine molecule is arranged in parallel to silicon surface and their binding takes place with a participation of presumably Van der Waals interaction (Figure 1).

2).

Cation of vinpocetine is bound similar to the base arranging in parallel to the surface of silicon (Figure

In case of the presence of functional groups $-\mathrm{H}$ and $-\mathrm{OH}$ on the surface of silicon vinpocetine takes different positions near interphase surface. In this situation hydrogen bonds participate in vinpocetine fixation (Figure 3).

Location of vinpocetine-cation near silicon surface in the presence of $-\mathrm{H}$ and $-\mathrm{OH}$ groups is perpendicular to the interphase surface (Figure 4).

From Figure 5 it can be seen that the location of vinpocetine cation relative to the non-ionized silicon oxide is perpendicular one while bonding occurs due to the polar groups of vinpocetine.

Vinpocetine is bound to the ionized surface of silicon oxide due to the polar groups and its molecule is perpendicular to the surface (Figure 6).

Vinpocetine-cation is bound to the ionized surface of silicon oxide due to the polar groups of vinpocetine as well as due to the ion interaction (Figure 7).

As a result of vibration analysis thermodynamic characteristics of the simulated fragments in the systems were obtained (enthalpy and entropy). The results are presented in Tables 1 and 2.
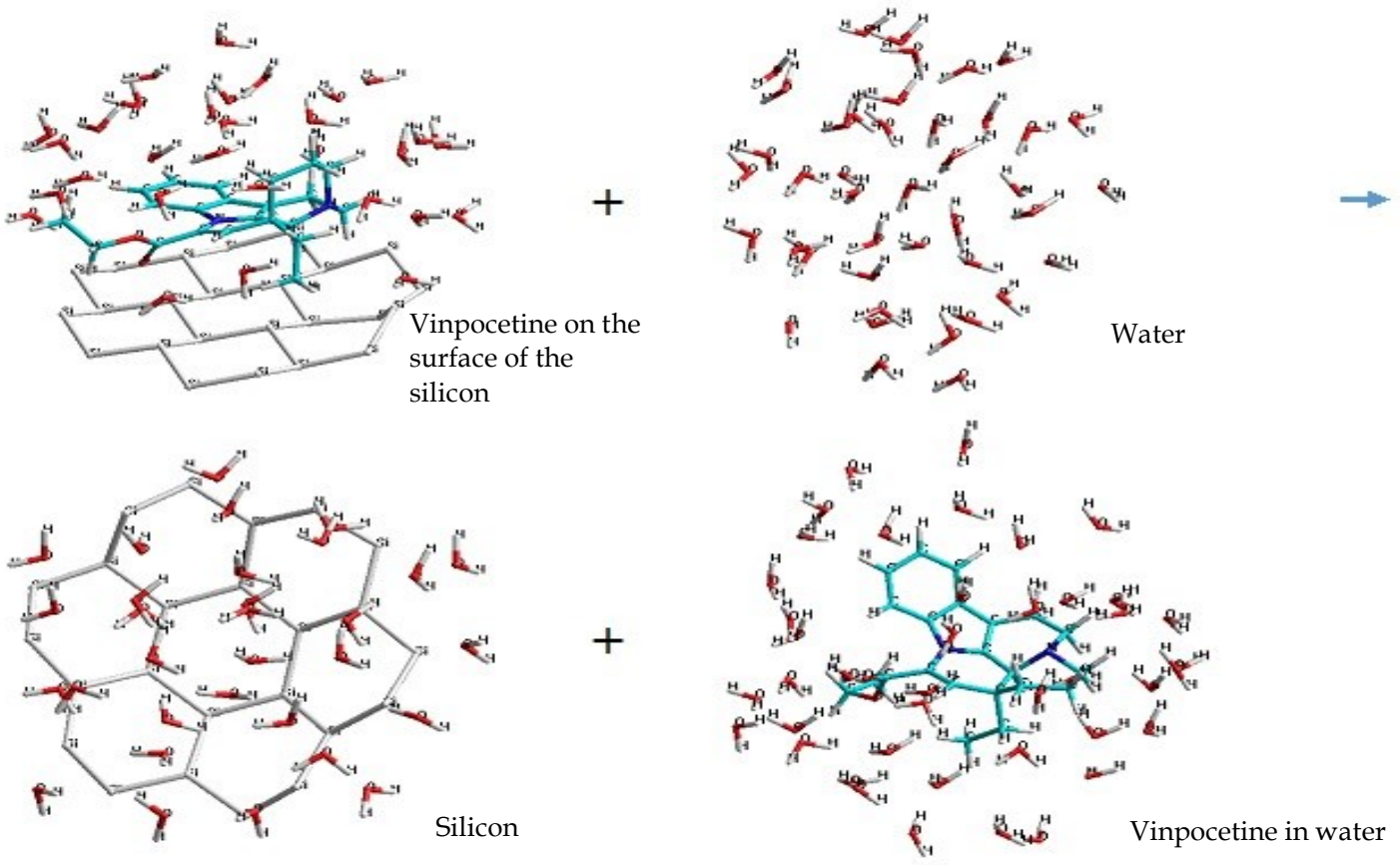

Figure 1. Desorption of Vinpocetine from the surface of the silicon in the water. 

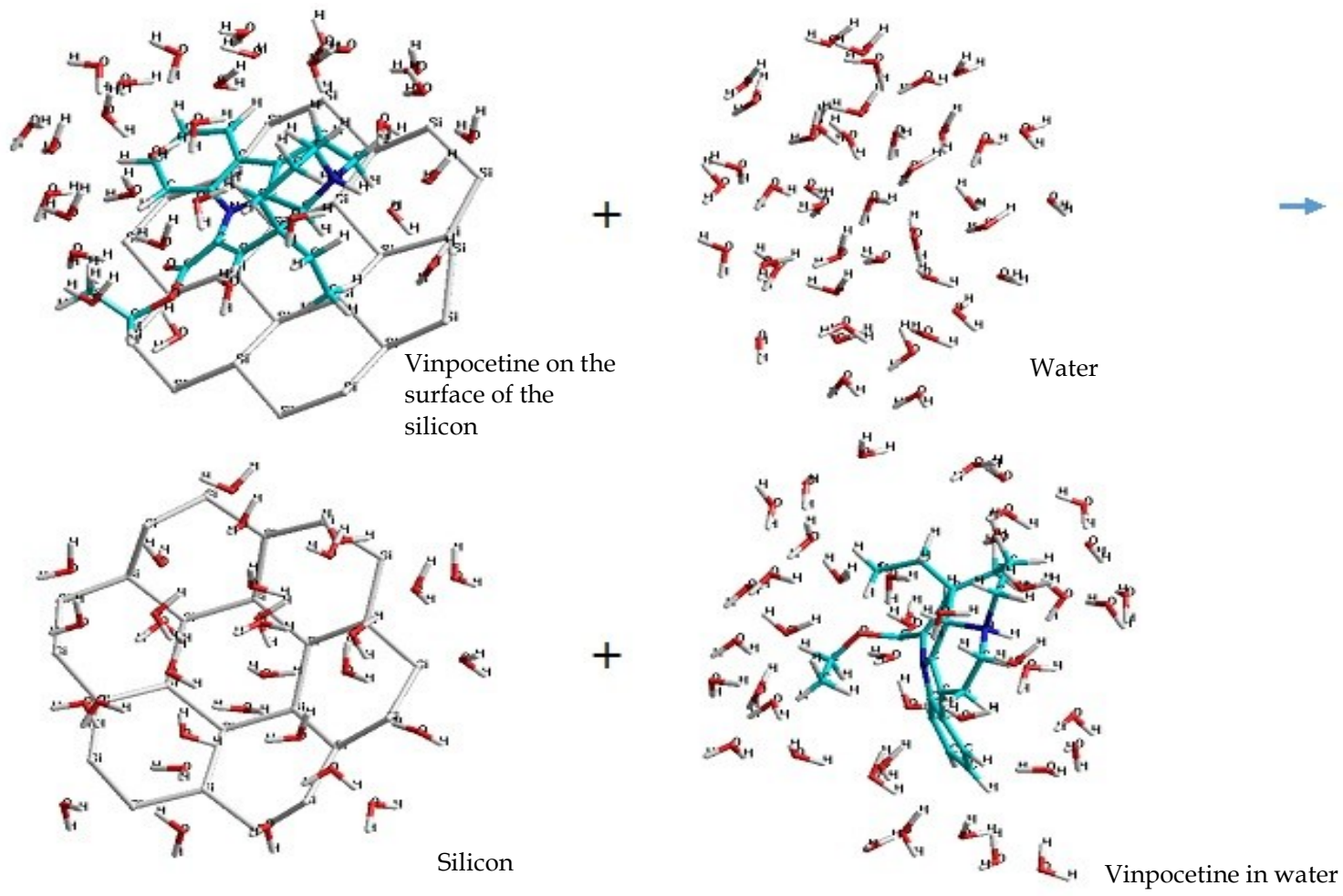

Figure 2. Desorption of the cation of Vinpocetine from the surface of silicon in water.

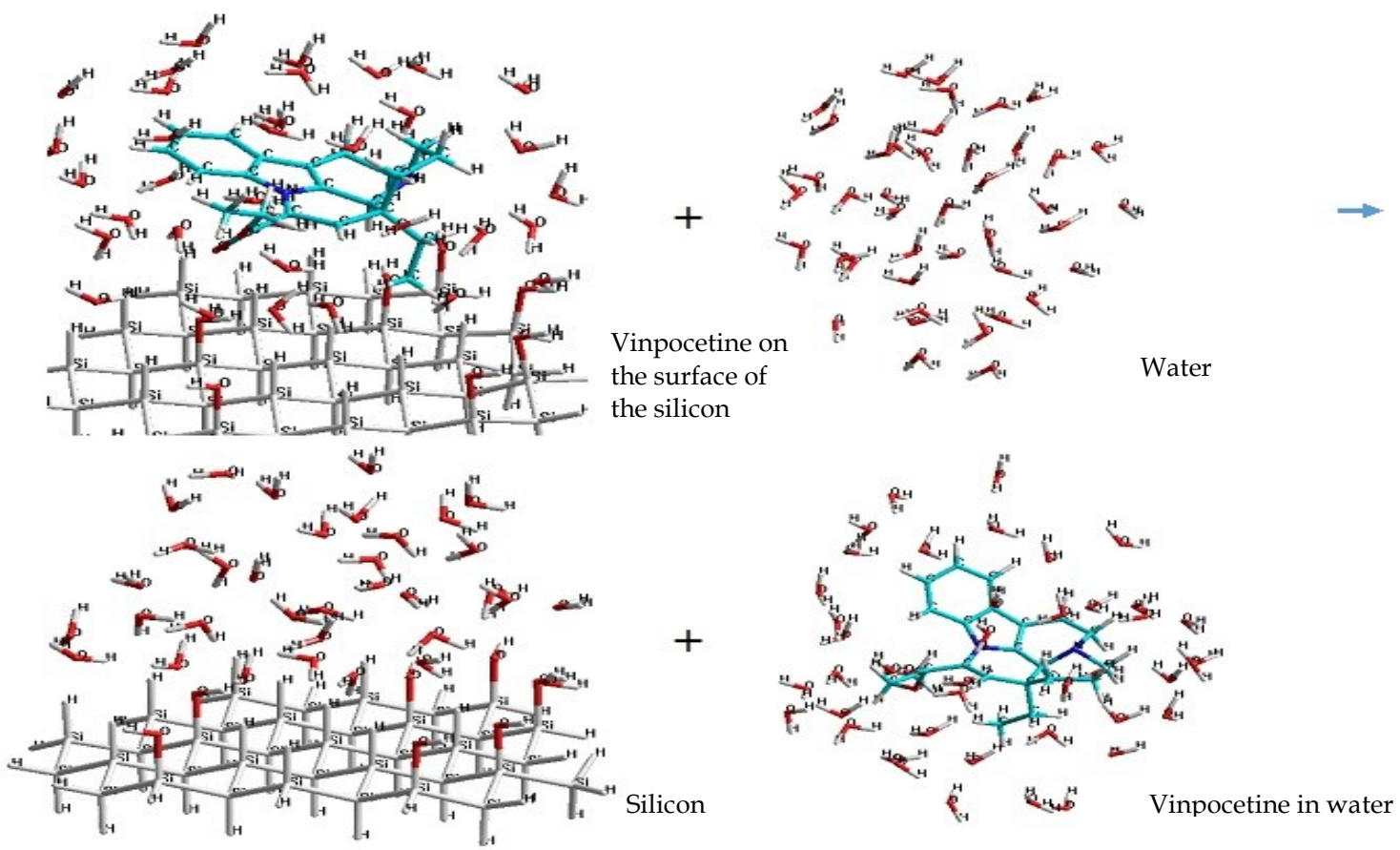

Figure 3. Desorption of Vinpocetine from the surface of the silicon groups $\mathrm{SiH}$ and $\mathrm{SiOH}$ in water. 

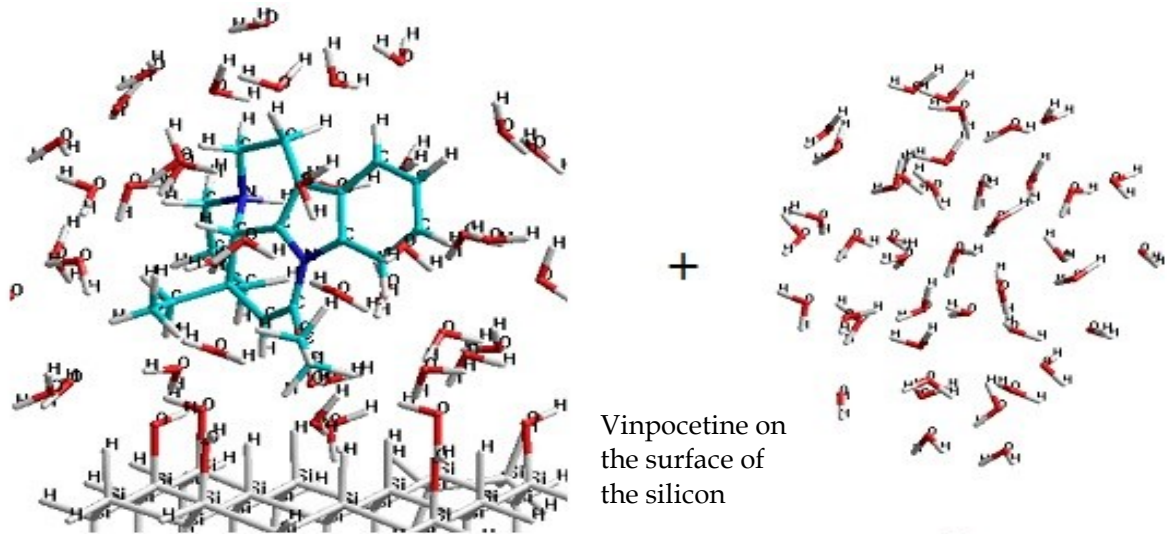

Water
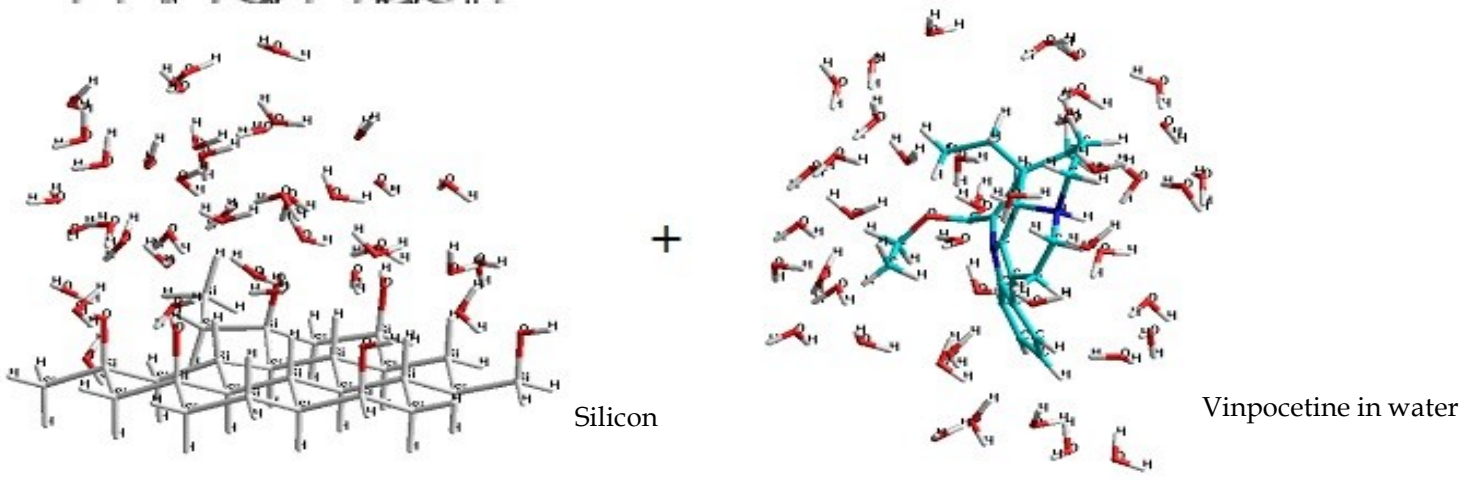

Figure 4. Desorption of the cation of Vinpocetine from the surface of the silicon groups $\mathrm{SiH}$ and $\mathrm{SiOH}$ in water.
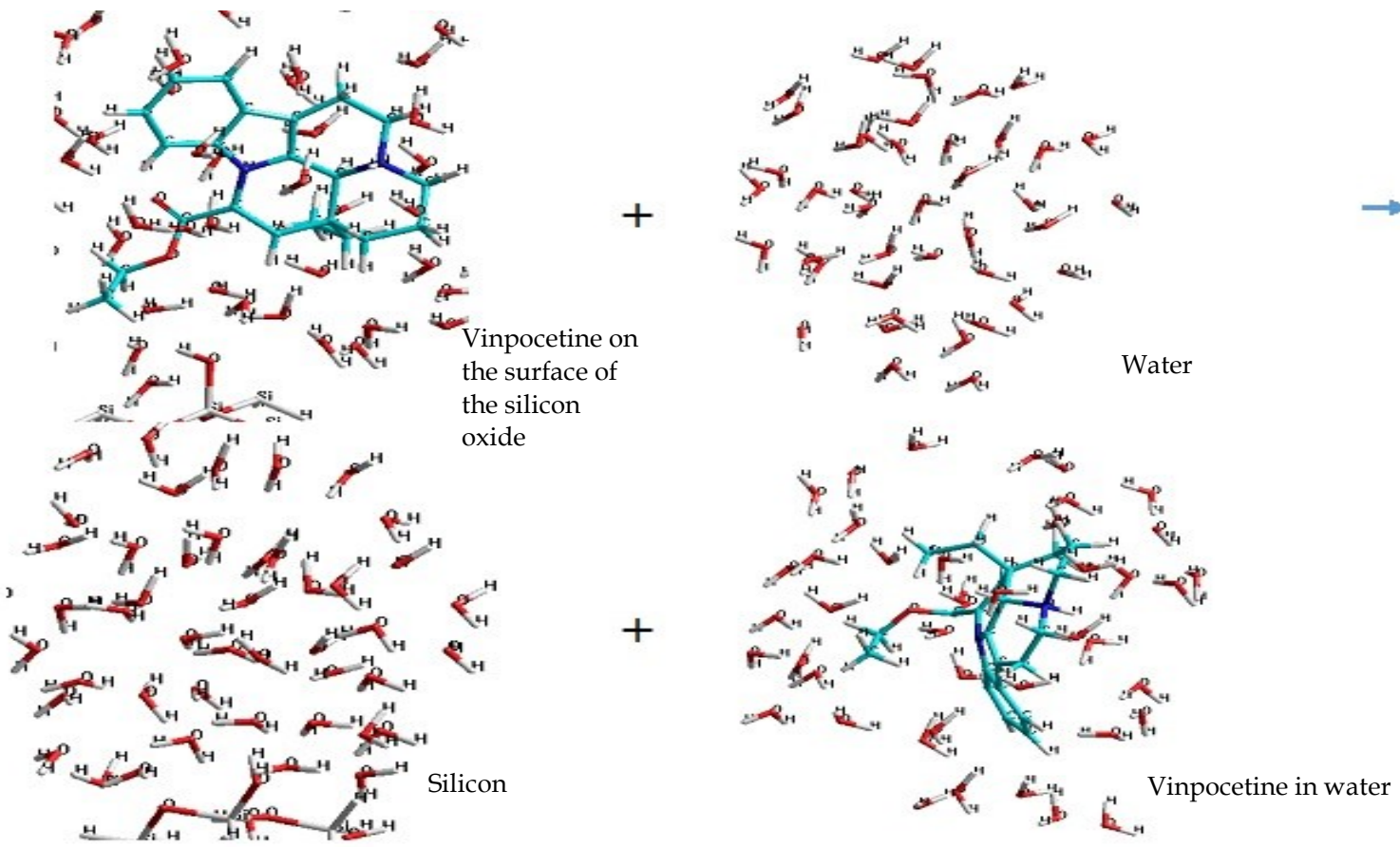

Figure 5. Desorption of the cation of Vinpocetine with uncharged surface of silicon oxide $\left(\mathrm{SiO}_{2}\right)$ in water. 

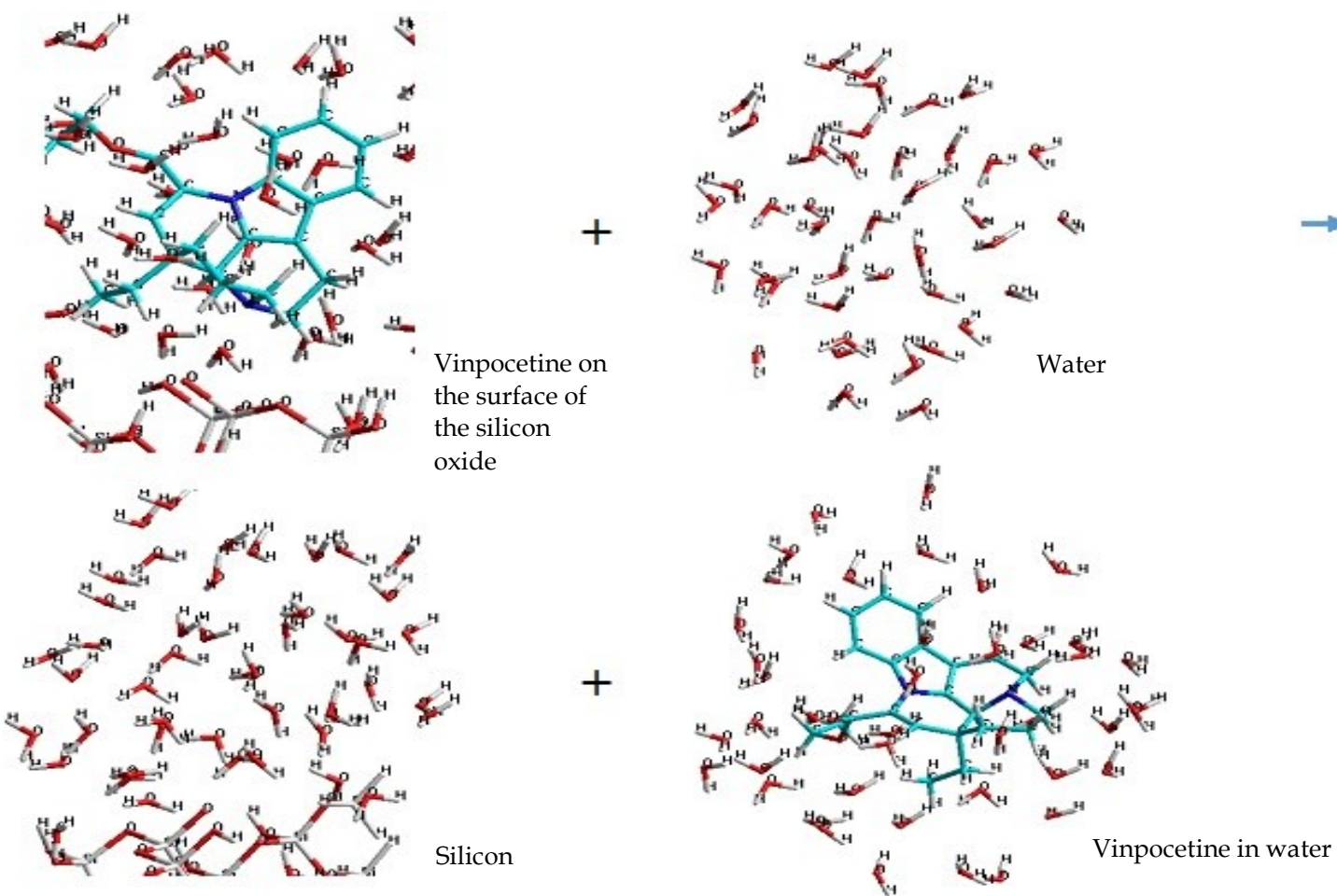

Figure 6. Desorption of Vinpocetine with ionized surface from silicon oxide $\left(\mathrm{SiO}_{2}\right)$ in water.

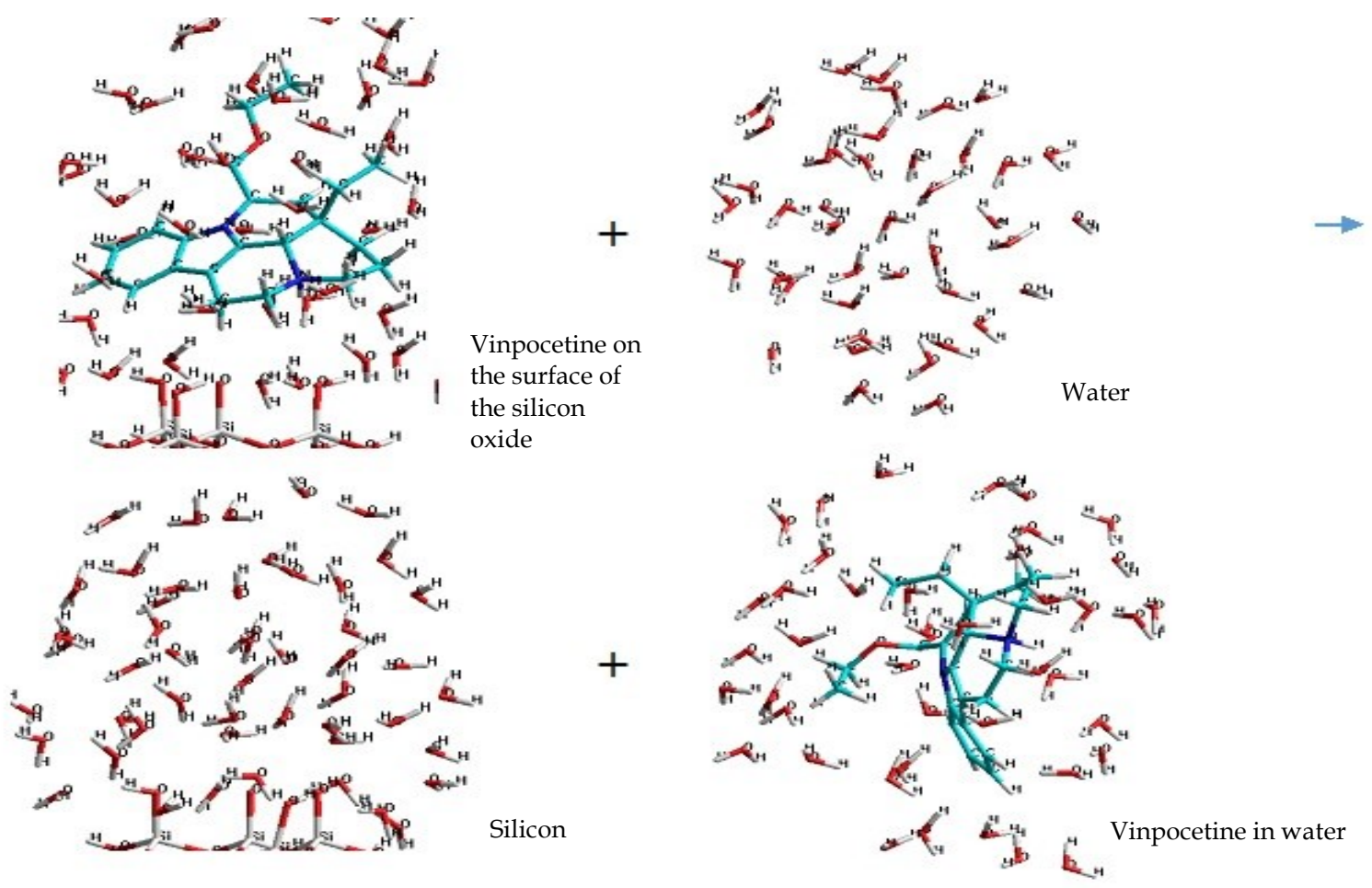

Figure 7. Desorption of the cation of Vinpocetine with ionized surface from silicon oxide $\left(\mathrm{SiO}_{2}\right)$ in water. 
Table 1. The results of quantum-chemical calculation of the enthalpy of desorption of Vinpocetine

\begin{tabular}{|c|c|c|c|c|c|}
\hline \multirow{2}{*}{ System } & \multicolumn{4}{|c|}{ Enthalpy of the system, $\mathrm{kJ} /$ mole } & \multirow{2}{*}{$\begin{array}{l}\text { Enthalpy of } \\
\text { desorption, } \\
\mathrm{kJ} / \text { mole }\end{array}$} \\
\hline & $\begin{array}{l}\text { Vinpocetine on } \\
\text { the adsorbent } \\
\text { surface }\end{array}$ & Solvent & $\begin{array}{l}\text { Adsorbent without } \\
\text { vinpocetine }\end{array}$ & $\begin{array}{l}\text { Vinpocetine in } \\
\text { solvent }\end{array}$ & \\
\hline Si - vinpocetine & -10269.14 & -3522.23 & -9176.46 & -4614.72 & 529.11 \\
\hline $\mathrm{Si}$ - vinpocetine + & -10269.57 & -3147.35 & -9176.46 & -4240.44 & 74.28 \\
\hline $\begin{array}{l}\mathrm{SiH}, \mathrm{SiOH}- \\
\text { vinpocetine }\end{array}$ & -14469.89 & -3522.23 & -13377.24 & -4614.72 & 429.26 \\
\hline $\begin{array}{l}\mathrm{SiH}, \mathrm{SiOH}- \\
\text { vinpocetine + }(1)^{*}\end{array}$ & -11909.16 & -3147.35 & -10815.97 & -4240.44 & 286.55 \\
\hline $\begin{array}{l}\mathrm{SiH}, \mathrm{SiOH}- \\
\text { vinpocetine + }(2)^{*}\end{array}$ & -10074.54 & -3147.35 & -8981.37 & -4240.44 & 233.18 \\
\hline $\begin{array}{l}\mathrm{SiO} 2 \text { (neutr.) - } \\
\text { vinpocetine }+(1)^{*}\end{array}$ & -6133.77 & -3147.35 & -5040.57 & -4240.44 & 301.13 \\
\hline $\begin{array}{l}\mathrm{SiO} 2 \text { (neutr.) - } \\
\text { vinpocetine + }(2)^{*}\end{array}$ & -6433.54 & -3147.35 & -5340.32 & -4240.44 & 358.98 \\
\hline
\end{tabular}

* - numbers in brackets indicate those ones of vinpocetine conformations on the surface of adsorbent

Table 2. The results of quantum-chemical calculation of the entropy of desorption of Vinpocetine

\begin{tabular}{|c|c|c|c|c|c|}
\hline \multirow[b]{2}{*}{ System } & \multicolumn{4}{|c|}{ Entropy of the system, $\mathrm{kJ} /$ mole } & \multirow{2}{*}{$\begin{array}{l}\text { Entropy } \\
\text { desorption, } \\
\mathrm{kJ} / \text { mole }\end{array}$} \\
\hline & $\begin{array}{l}\text { Vinpocetine on } \\
\text { the adsorbent } \\
\text { surface }\end{array}$ & Solvent & $\begin{array}{l}\text { Adsorbent } \\
\text { without } \\
\text { vinpocetine }\end{array}$ & $\begin{array}{l}\text { Vinpocetine in } \\
\text { solvent }\end{array}$ & \\
\hline Si - vinpocetine & 0.1797 & 0.1704 & 0.1750 & 0.1769 & 0.001821 \\
\hline $\mathrm{Si}$ - vinpocetine + & 0.1789 & 0.1679 & 0.1750 & 0.1760 & 0.004103 \\
\hline $\begin{array}{l}\mathrm{SiH}, \mathrm{SiOH}- \\
\text { vinpocetine }\end{array}$ & 0.1863 & 0.1704 & 0.1832 & 0.1769 & 0.003341 \\
\hline $\begin{array}{l}\mathrm{SiH}, \mathrm{SiOH}- \\
\text { vinpocetine }+(1)^{*}\end{array}$ & 0.1846 & 0.1679 & 0.1806 & 0.1760 & 0.004015 \\
\hline $\begin{array}{l}\mathrm{SiH}, \mathrm{SiOH}- \\
\text { vinpocetine }+(2)^{*}\end{array}$ & 0.1847 & 0.1679 & 0.1801 & 0.1760 & 0.003462 \\
\hline $\begin{array}{l}\mathrm{SiO} 2 \text { (neutr.) - } \\
\text { vinpocetine }+(1)^{*}\end{array}$ & 0.1794 & 0.1679 & 0.1746 & 0.1760 & 0.003228 \\
\hline $\begin{array}{l}\mathrm{SiO} 2 \text { (neutr.) - } \\
\text { vinpocetine }+(2)^{*}\end{array}$ & 0.1803 & 0.1679 & 0.1759 & 0.1760 & 0.003580 \\
\hline
\end{tabular}

* - numbers in brackets indicate those ones of vinpocetine conformations on the surface of adsorbent

\section{DISCUSSION}

On the basis of quantum-chemical calculations for enthalpy of vinpocetine desorption from the surface of silicon and silicon oxide it is possible to conclude that the release of vinpocetine cation from the surface of silicon and silicon oxide is more advantageous in energy as compared with the vinpocetine base.

A positive value of entropy desorption for vinpocetine while its release from the surface of silicon and silicon oxide into the aqueous environment is a factor facilitating the release of this substance.

Table 3 provides the results of quantum-chemical calculations for Gibbs energy in desorption of vinpocetine.

Results of quantum-chemical calculations for Gibbs energy of vinpocetine desorption from the surface of silicon and silicon oxide enabled to consider the influence of entropy and temperature on the energy of desorption. The obtained results indicate at the higher affinity of vinpocetine to the adsorbent if the former one is in the form of base as compared with cation state.

These results were further employed for the estimation of thermodynamic characteristics for adsorption of vinpocetine on silicon and silicon oxide under different values of $\mathrm{pH}$ in solvent (water). 
Table 3. The results of quantum-chemical calculation of Gibbs energy of desorption of Vinpocetine.

\begin{tabular}{|c|c|c|c|c|c|}
\hline \multirow[b]{2}{*}{ System } & \multicolumn{4}{|c|}{ Gibbs energy of the system, $\mathrm{kJ} / \mathrm{mole}$} & \multirow{2}{*}{$\begin{array}{l}\text { Gibbs energy } \\
\text { of desorption, } \\
\mathrm{kJ} / \text { mole }\end{array}$} \\
\hline & $\begin{array}{l}\text { Vinpocetine on } \\
\text { the adsorbent } \\
\text { surface }\end{array}$ & Solvent & $\begin{array}{l}\text { Adsorbent } \\
\text { without } \\
\text { vinpocetine }\end{array}$ & $\begin{array}{l}\text { Vinpocetine in } \\
\text { solvent }\end{array}$ & \\
\hline Si - vinpocetine & -10324.84 & -3575.05 & -9230.70 & -4669.55 & 528.54 \\
\hline $\mathrm{Si}$ - vinpocetine + & -10325.04 & -3199.41 & -9230.70 & -4294.99 & 73.01 \\
\hline $\mathrm{SiH}, \mathrm{SiOH}$ - vinpocetine & -14527.66 & -3575.05 & -13434.03 & -4669.55 & 428.22 \\
\hline $\begin{array}{l}\mathrm{SiH}, \mathrm{SiOH} \text { - vinpocetine } \\
+(1)^{*}\end{array}$ & -11966.38 & -3199.41 & -10871.94 & -4294.99 & 285.31 \\
\hline $\begin{array}{l}\mathrm{SiH}, \mathrm{SiOH} \text { - vinpocetine } \\
+(2)^{*}\end{array}$ & -10131.79 & -3199.41 & -9037.19 & -4294.99 & 232.11 \\
\hline $\begin{array}{l}\mathrm{SiO} 2 \text { (neutr.) - } \\
\text { vinpocetine + }(1)^{*}\end{array}$ & -6189.39 & -3199.41 & -5094.69 & -4294.99 & 300.13 \\
\hline $\begin{array}{l}\mathrm{SiO} 2 \text { (neutr.) - } \\
\text { vinpocetine + }(2)^{*}\end{array}$ & -6489.45 & -3199.41 & -5394.84 & -4294.99 & 357.87 \\
\hline
\end{tabular}

* - numbers in brackets indicate those ones of vinpocetine conformations on the surface of adsorbent

Considering index of the dissociation constant for vinpocetine $\mathrm{pKa}=7,1$ [15] and using HendersonHasselbach equation [16] it is possible to calculate the relative content of vinpocetine-base and vinpocetinecation in a solution:

$$
\begin{aligned}
& \alpha=\frac{10^{p H-p K a}}{1+10^{p H-p K a}}, \\
& \beta=1-\alpha,
\end{aligned}
$$

where $\alpha$ and $\beta$ are relative content values of vinpocetine-base and vinpocetine-cation, respectively, in the solution.

Taking into account the shares of ionized and non-ionized molecules of vinpocetine at the different $\mathrm{pH}$ values and thermodynamic characteristics of adsorption obtained for both forms of vinpocetine at different adsorbents thermodynamic characteristics of desorption were calculated for the different values of $\mathrm{pH}$ (Figure 8).

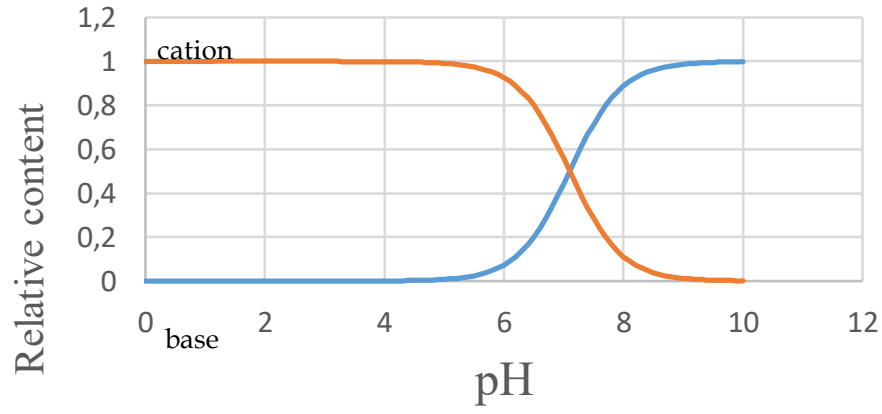

Figure 8. The relative content of Vinpocetine-Vinpocetine and base-cation in the solution according to the equation of Henderson-Hasselbach.

To perform these procedures weighted average values of enthalpy, entropy and Gibbs energy of desorption were also calculated. Relative content of vinpocetine and vinpocetine-cation was employed as weighting coefficients for different $\mathrm{pH}$ values (Table 4).

Calculations of thermodynamic characteristics for vinpocetine desorption from the surface of silicon and silicon oxide with the account of the dependence of vinpocetine ionization under different values of $\mathrm{pH}$ enable to make a conclusion on the more tight binding for this preparation with the adsorbents at $\mathrm{pH}=6.8$ and 7.0 as compared with $\mathrm{pH}=2.0$. Moreover, the obtained data allow to make an assumption that vinpocetine adsorption is more efficient on silicon oxide at the corresponding values of $\mathrm{pH}$. Obviously, this can be explained by a greater amount of donors and acceptors of the hydrogen bond on the surface o silicon oxide as well as the ability of silicon oxide to ionization and, hence, by involving of the ion adsorption. 
Table 4. Thermodynamic characteristics of Vinpocetine desorption from the surface of silicon and silica for different $\mathrm{pH}$ values.

\begin{tabular}{lcccccc}
\hline Adsorbent & $\mathrm{pH}$ & Share of base & Cation share & $\Delta \mathrm{H}, \mathrm{kJ} / \mathrm{mole}$ & $\Delta \mathrm{S}, \mathrm{kJ} /\left(\mathrm{mole} \mathrm{K}^{*}\right.$ & $\Delta \mathrm{G}, \mathrm{kJ} / \mathrm{mole}$ \\
\hline $\mathrm{Si}$ & 2.0 & 0.00 & 1.00 & 74.28 & 0.004103 & 73.01 \\
$\mathrm{Si}$ & 6.8 & 0.33 & 0.67 & 226.13 & 0.003341 & 225.09 \\
$\mathrm{Si}$ & 7.0 & 0.44 & 0.56 & 275.63 & 0.003091 & 274.67 \\
$\mathrm{Si}$ with -H and -OH & 2.0 & 0.00 & 1.00 & 259.87 & 0.003739 & 258.71 \\
radicals & & & & & & \\
$\mathrm{Si}$ with -H and -OH & 6.8 & 0.33 & 0.67 & 316.42 & 0.003606 & 315.30 \\
$\begin{array}{l}\text { radicals } \\
\mathrm{Si} \text { with -H and -OH }\end{array}$ & 7.0 & 0.44 & 0.56 & 334.86 & 0.003563 & 333.75 \\
$\begin{array}{l}\text { radicals } \\
\mathrm{SiO}\end{array}$ & 2.0 & 0.00 & 1.00 & 330.05 & 0.003404 & 328.00 \\
$\mathrm{SiO}_{2}$ & 6.8 & 0.33 & 0.67 & 349.10 & 0.003334 & 348.07 \\
$\mathrm{SiO}_{2}$ & 7.0 & 0.44 & 0.56 & 364.28 & 0.003265 & 363.27 \\
\hline
\end{tabular}

\section{CONCLUSION}

The performed calculations showed that the efficiency of vinpocetine release from the particles of silicon and silicon oxide $\left(\mathrm{SiO}_{2}\right)$ is related with thermodynamic characteristics of the desorption process. Comparison of Gibbs energy for the desorption of vinpocetine from the surface of non-substituted silicon and silicon with $-\mathrm{H}$ and $-\mathrm{OH}$ groups on the surface makes it possible to conclude that vinpocetine is more tightly bound in the presence of hydroxyl groups on the surface of an adsorbent. Probably, it can be explained by formation of hydrogen bonds between an adsorbate and adsorbent. Gibbs energy of the desorption for vinpocetine from the surface of silicon oxide is greater as compared with that one for the desorption from the surface of silicon under corresponding $\mathrm{pH}$ values. It can be possibly explained by the capability of silicon oxide surface to its ionization at $\mathrm{pH} 6.8$ and 7.0, as well as by a great amount of hydroxyl groups on the surface of this adsorbent.

The obtained data arrive at the conclusion on more tight binding of vinpocetine with the surface of silicon oxide as compared with pure silicon surface.

Basing on the calculations one can also make a conclusion on the decrease of the bond strength between vinpocetine and the surface of silicon and silicon oxide under decrease of the $\mathrm{pH}$ value.

\section{MATERIALS AND METHODS}

Calculations of enthalpy, entropy and Gibbs energy were performed for the desorption process of vinpocetine from the surface of an adsorbent [17-19]. To make the calculations first enthalpy and entropy of the initial and ultimate states of the process were preliminarily calculated. Adsorbate conformations at the interphase surface were taken as the initial states while for the ultimate state vinpocetine in the aqueous environment and adsorbent surface in its contact with water were considered. In order to calculate thermodynamic characteristics of vinpocetine desorption from the surface of silicon and silicon oxide conformations of vinpocetine molecule near the surface of adsorbent were applied that were previously obtained in the process of molecular dynamics simulation. Optimization of the geometric conformation was performed in the force field of Amber94 [20] in the program suite of Bioevrika [21-23].

Vibration analysis for the isolated systems [24] was performed with the use of infinite Hartree-Fock method in STO-3G basis realized in the program Orca 4.0.

Calculations of enthalpy $(\Delta \mathrm{H} \Delta H) \Delta \mathrm{H}$ and entropy $(\Delta \mathrm{P} \Delta H) \Delta S$ of vinpocetine desorption was realized according to the formulas:

$$
\begin{aligned}
& \text { (Eq. 1) } \Delta H=\left(H_{\text {adsorbent }}+H_{\text {vinp.-solvent }}\right)-\left(H_{\text {vinp.-adsorbent }}+H_{\text {solvent }}\right) \\
& \text { (Eq. 2) } \Delta S=\left(S_{\text {adsorbent }}+S_{\text {vinp.-solvent }}\right)-\left(S_{\text {vinp.-adsorbent }}+S_{\text {solvent }}\right)
\end{aligned}
$$

With the use of obtained values for enthalpy and entropy Gibbs energy values $(\Delta \mathrm{G})$ for the desorption of vinpocetine were calculated for the temperature of $310 \mathrm{~K}$ according to the formula:

(Eq. 3) $\Delta \mathrm{G}=\Delta \mathrm{H}-(\mathrm{T} \Delta \mathrm{S})$,

where $\mathrm{T}$ is temperature, $\mathrm{K}$. 
Acknowledgements: The authors thank of the grant of the Council on the grants of the President of RF CП-95.2018.4.

Author contributions: Concept -Y.P., A.L.; Design - Y.P., P.S.; Supervision - Y.P., A.L.; Resource Y.P., A.L.; Materials - Y.P. Data Collection and/or Processing - Y.P., A.L., P.S.; Analysis and/or Interpretation - Y.P., A.L.; Literature Search - Y.P., A.L., K.K.; Writing - Y.P., A.L.; Critical Reviews - Y.P., A.L., P.S., K.K

Conflict of interest statement: The authors declared no conflict of interest.

\section{REFERENCES}

[1] Duncan R, Vicent MJ, Greco F, Nicholson R. Polymer-drug conjugates: towards a novel approach for the treatment of endrocine-related cancer. Endocr Relat Cancer. 2005; 12(1): 189-199.

[2] Denisse Rocha-García, Antonio Guerra-Contreras, Sergio Rosales-Mendoza, Gabriela Palestino. Role of porous silicon/hydrogel composites on drug delivery. Mesoporous Biomater. 2016; 3: 93-101.

[3] Canham L. Handbook of Porous Silicon. Springer. New York, 2014, pp.156-160.

[4] Bisia O, Ossicinib Stefano, Pavesi L. Porous silicon: a quantum sponge structure for silicon based optoelectronics. Surf Sci Rep. 2000: 38(1-3), 1-126.

[5] Vivero-Escoto JL, Slowing II, Trewyn BG, Lin VSY. Mesoporous silica nanoparticles for intracellular controlled drug delivery. Small. 2010; 6(18): 1952-1967.

[6] Bobyl A, Konnikov S, Sakseev D, Soldatenkov F, Tereschenko G, Ulin V. Porous-semiconductor-based hydrogenpermeable membrane. Ind Eng Chem Res. 2007; 46(8): 2263-2267.

[7] Jarvis KL, Barnes TJ, Prestidge CA. Surface chemistry of porous silicon and implications for drug encapsulation and delivery applications. Adv Colloid Interface Sci. 2012; 175: 25-38.

[8] Golob S, Perry M, Lusi M, Chierotti MR, Grabnar I, Lassiani L, Voinovich D, Zaworotko MJ. Improving biopharmaceutical properties of vinpocetine through cocrystallization. J Pharm Sci. 2016; 105(12): 3626 - 3633.

[9] Arruebo M. Drug delivery from structured porous inorganic materials. WIREs Nanomed Nanobiotechnol. 2012; 4(1): $16-21$.

[10] Wu EC, Andrew JS, Cheng L, Freeman WR, Pearson L, Sailor MJ. Real-time monitoring of sustained drug release using the optical properties of porous silicon photonic crystal particles. Biomaterials. 2011; 32(7): 1957-1966.

[11] Ding J, Li J, Shirui Mao. Development and evaluation of vinpocetine inclusion complex for brain targeting. Asian J Pharm Sci. 2015; 10(2): 114-120.

[12] Pochert A, Schneider D, Haase J, Linden M, Valiullin R. Diffusion and molecular exchange in hollow core-shell silica nanoparticles. Langmuir. 2015; 31(37): 10285 -10295.

[13] Polkovnikova YA, Lenshin AS, Seredin PV, Minakov DA. Porous silicon nanoparticles containing neurotropic drugs. Inorg Mater. 2017; 53(5): 477-483.

[14] Polkovnikova YA, Lenshin AS, Seredin PV. Studies on the development of nanoparticles with afobazole on the basis of porous silicon. Russ J Biopharm. 2017; 9(2): 43-47.

[15] Berendsen HJC, Postma JPM, Gunsteren WF, DiNola A, Haak JR. Molecular dynamics with coupling to an external bath. J Chem Phys. 1984; 81(8): 3684-3690.

[16] Bykov D, Petrenko T, Izsák R, Kossman S, Becker U, Neese F. Efficient implementation of the analytic second derivatives of hartree-fock and hybrid dft energies: a detailed analysis of different approximations. Mol Phys. 2015; 113(13): 1961-1987.

[17] Greiner M, Sonnleitner B, Mailänder M, Briesen H. Modeling complex and multi-component food systems in molecular dynamics simulations on the example of chocolate conching. Food Funct. 2014; 5(2): 235-242.

[18] Feller SE. Molecular dynamics simulations of lipid bilayers. Curr Opin Collolid Interface Sci 2000; 5(3): $217-223$.

[19] Leo D, Maranon J. Confined water/oil interface. Molecular dynamics study. J Mol Struct (Theochem). 2004; 672(1-3): 221-229.

[20] Sedghi M, Piri M, Goual L. Atomistic molecular dynamics simulations of crude oil/brine displacement in calcite mesopores. Langmuir. 2016; 32(14): 3375-3384. 
[21] Arivazhagana M, Manivela S, Jeyavijayanb S. Vibrational spectroscopic (FTIR and FT-Raman), first-order hyperpolarizablity, HOMO, LUMO, NBO, Mulliken charge analyses of 2-ethylimidazole based on Hartree-Fock and DFT calculations. Spectrochim Acta A. 2015; 134: 493-501.

[22] Ramakrishnan SK, Estephan E, Martin M, Cloitre T, Gergely C. Molecular Mechanism of Selective Binding of Peptides to Silicon Surface. J Chem Inf Model. 2014; 54(7): 2117-2126.

[23] Emami FS, Puddu V, Berry R, Heinz H. Force field and a surface model database for silica to simulate interfacial properties in atomic resolution. Chem Mater. 2014; 26(8): 2647-2658.

[24] Cornell WD, Cieplak P, Bayly CI, Gould IR, Merz KM, Ferguson DM, Spellmeyer DC, Fox T, Caldwell JW, Kollman PA. A second generation force field for the simulation of proteins, nucleic acids, and organic molecules. J Am Chem Soc. $1995 ;$ 117(19): 5179-5197.

This is an open access article which is publicly available on our journal's website under Institutional Repository at http://dspace.marmara.edu.tr. 